\title{
PENGARUH INFLASI TERHADAP PROFITABILITAS PADA BANK SYARIAH DAN BANK KONVENSIONAL PERIODE TAHUN 2015-2018
}

(Studi Kasus PT. Bank Rakyat Indonesia Syariah.Tbk dan PT. Bank

Rakyat Indonesia.Tbk)

\author{
Yayan Nasikin \\ IAIN Fattahul Muluk Papua \\ yayannasikin@gmail.com \\ Sahudi \\ IAIN Fattahul Muluk Papua \\ sahudionline@gmail.com \\ Amris \\ IAIN Fattahul Muluk Papua \\ amris@iainpapua.ac.id
}

\begin{abstract}
This article aims to analyze the influence of inflation on profitability of islamic banking and conventional banking in the period 2015-2018 (a case study of PT. Bank Rakyat Indonesia Syariah. (persero). Tbk and PT. bank rakyat indonesia (persero). tbk). This research is a quantitative study which uses secondary data obtained from the official pages of the Financial Services Authority (OJK) and Bank Indonesia. The analysis technique used is simple linear regression using the Microsoft Office Excel program. The results show that the inflation has negative and unsignificant effects on the Retrun On Asset (ROA) of PT. Bank Rakyat Indonesia Syariah. (Persero). Tbk and PT. Bank Rakyat Indonesia (Persero) .Tbk). On another hand, the effect of the inflation rate on PT. Bank Rakyat Indonesia Syariah (Persero). Tbk is smaller than PT. Bank Rakyat Indonesia (Persero) .Tbk. This is due to the fact that Islamic banks do not use the interest system but instead use a profit sharing system, so that the money managed by Islamic banks is not very influential when there is an increase in inflation. The results of this study are expected to be input for interested parties especially Islamic banks and conventional banks to make decisions in determining company policy.
\end{abstract}

Keywords: Inflation, Return On Assets (ROA), Islamic Banks, Conventional Banks. 


\begin{abstract}
ABSTRAK
Artikel ini bertujuan untuk menganalisis pengaruh inflasi terhadap profitabilitas pada bank syariah dan bank konvensional periode tahun 2015-2018 (studi kasus PT. Bank Rakyat Indonesia Syariah.(Persero).Tbk dan PT. Bank Rakyat Indonesia (Persero).Tbk). Penelitian ini adalah penelitian kuantitatif dengan menggunakan data sekunder yang diperoleh dari halaman resmi Otoritas Jasa Keuangan (OJK) dan Bank Indonesia. Teknik analisis yang digunakan adalah regresi linear sederhana menggunakan program Microsoft Office Excel. Hasil penelitian menunjukkan bahwa Inflasi memiliki pengaruh negatif dan tidak signifikan terhadap Retrun On Asset (ROA) PT. Bank Rakyat Indonesia Syariah.(Persero).Tbk dan PT. Bank Rakyat Indonesia (Persero).Tbk). Namun Pengaruh tingkat inflasi pada PT. Bank Rakyat Indonesia Syariah (Persero).Tbk lebih kecil dibandingkan dengan PT. Bank Rakyat Indonesia(Persero).Tbk. hal ini disebabkan bank syariah tidak menggunakan sistem bunga melainkan menggunakan sistem bagi hasil sehingga uang yang dikelola bank syariah tidak terlalu berpengaruh apabila terjadi peningkatan inflasi. Hasil dari penelitian ini diharapakan dapat menjadi masukan bagi pihak yang berkepentingan khususnya bank syariah dan bank konvensional untuk mengambil keputusan dalam menentukan kebijakan perusahaan.
\end{abstract}

Kata kunci : Inflasi, Retrun On Asset (ROA), Bank Syariah, Bank Konvensional.

\title{
PENDAHULUAN
}

Bank memiliki peranan penting dalam perekonomian suatu negara. Hampir semua aktivitas perekonomian baik barang maupun jasa memanfaatkan perbankan sebagai lembaga keuangan yang dapat menjamin berjalannya aktivitas bisnis maupun usaha. Hal ini disebabkan karena bank merupakan lembaga finansial yang memiliki peranan pokok yaitu sebagai lembaga keuangan yang memiliki peranan mempertemukan antara pihak yang mempunyai modal dengan pihak-pihak yang membutuhkan modal serta sebagai lembaga yang berperan mempermudah alur lalu lintas pembayaran. Menurut Undang - Undang No. 10 Tahun 1998 bank adalah badan usaha yang menghimpun dana dari masyarakat dalam bentuk simpanan dan menyalurkan kepada masyarakat dalam bentuk kredit dan bentuk-bentuk lainnya dalam rangka meningkatkan taraf hidup masyarakat banyak (Undang - Undang No 10 Tahun 1998).

Indonesia sendiri menggunakan dual banking system yaitu sistem perbankan syariah dan sistem perbankan konvensional hal ini sesuai dengan Undang - Undang No. 7 Tahun 1992 tentang perbankan yang disahkan pada tanggal 25 Maret 1992 yang selanjutnya diamandemen menjadi Undang Undang No. 10 tahun 1998 yang disahkan pada tanggal 10 November 1998 (Darsono, 2013, hlm. 17). 
Dalam menjalankan operasionalnya faktor internal dan faktor eksternal sangat mempengaruhi bank syariah maupun bank konvensional. Hal ini tentunya akan berdampak pada profitabilitas bank. Profitabilitas merupakan kemampuan suatu perusahaan untuk mendapatkan laba dalam suatu periode tertentu (Kasmir, 2014, hlm. 34). Proifitabilitas menjadi sangat penting untuk diukur karena profitabilitas bank tidak hanya penting bagi pihak perusahaan saja, tetapi penting juga bagi golongan-golongan lain yaitu masyarakat, investor, dan juga pemerintah. Salah satu indikator yang digunakan untuk mengukur kemampuan manajemen bank dalam memperoleh laba atau keuntungan (profitabilitas) adalah Return On Asset (ROA). Return On Asset (ROA) adalah rasio antara laba bersih terhadap total aset (Sujarweni, 2017, hlm. 65).

Inflasi merupakan Salah satu faktor eksternal yang diduga berpengaruh terhadap profitabilitas bank syariah maupun bank konvensional. Inflasi menurut kamus adalah kemerosotan nilai mata uang (kertas) karena terlalu banyak beredar dan menyebabkan melambungnya harga barang barang (www.kbbi.co.id). Berikut adalah perkembangan inflasi periode 2015 - 2018 .

\section{Gambar 1 Perkembangan Inflasi}

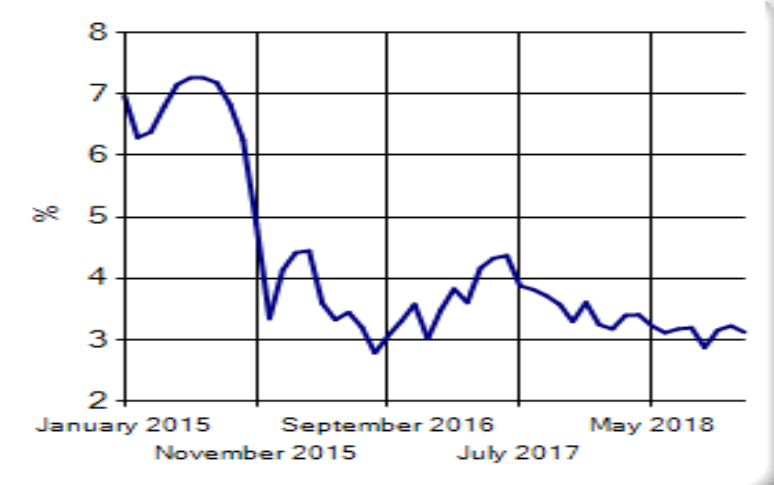

(Sumber : www.bi.go.id)

Pada gambar 1 terlihat perkembangan nilai inflasi cukup fluktuatif dari tahun 2015 sampai dengan tahun 2018. Pada tahun 2015 inflasi berada pada titik $6,96 \%$ namun selanjutnya meningkat sampai pada titik 7,26\%. Inflasi yang tinggi akan menyababkan nilai intrinsik dan nilai ril tabungan merosot, karena masyarakat akan cenderung mempergunakan hartanya untuk mencukupi biaya pengeluaran akibat naiknya harga-harga barang, hal tersebut akan mempengarui profitabilitas bank.

Penelitian ini bertujuan untuk mengetahui pengaruh inflasi terhadap profitabilitas pada bank syariah dan bank konvensional periode tahun 20152018 (studi kasus PT. Bank Rakyat Indonesia Syariah.(Persero).Tbk dan PT. Bank Rakyat Indonesia (Persero).Tbk). Adapun manfaat dari pada penelitian ini adalah Sebagai sumbangan pemikiran yang akan berguna bagi pihak-pihak yang membutuhkan dan hasil dari penelitian ini diharapkan dapat menjadi 
bahan edukasi serta dapat menjadi bahan masukan bagi masyarakat dalam melakukan investasi.

\section{KAJIAN LITERATUR}

\section{Konsep Bank}

Menurut Undang-Undang No. 10 tahun 1998, yang dimaksud dengan perbankan adalah segala sesuatu yang menyangkut tentang bank, mencakup kelembagaan, kegiatan usaha, serta cara dan proses dalam melaksanakan kegiatan usahanya sedangkan yang dimaksud dengan bank adalah suatu badan usaha yang menghimpun dana dari masyarakat dalam bentuk simpanan dan menyalurkannya kepada masyarakat, dalam bentuk kredit dan atau bentuk-bentuk lainnya dalam rangka meningkatkan taraf hidup rakyat (Undang - Undang No 10 Tahun 1998).

Bank berasal dari kata Italia banco yang artinya bangku. Bangku inilah yang dipergunakan oleh bankir untuk melayani kegiatan operasionalnya kepada para nasabah. Secara resmi istilah bangku populer menjadi bank (Hasibuan, 2017, hlm. 1). Kasmir dalam bukunya yang berjudul manajemen perbankan mengatakan yang dimaksud dengan bank adalah lembaga finansial yang dalam oprasionalnya mengumpulkan dana dan mendistribusikan kembali dana tersebut ke masyarakat serta menyediakan jasa bank lainnya (Kasmir, 2017, hlm. 12).

Bank merupakan institusi yang memiliki kewenangan menerima simpanan yang bertujuan memfasilitasi pembiayaan jangka pendek dan jangka panjang (Usanti dan Shomad, 2016, hlm. 11). Berdasarkan PSAK No. 31, Bank adalah suatu lembaga yang berperan sebagai perantara keuangan (Financial Intermediary) antara pihak-pihak yang memiliki kelebihan dana (Surplus Unit) dengan pihak-pihak yang memerlukan dana (Deficit Unit), serta sebagai lembaga yang berfungsi memperlancar lalu lintas pembayaran (PSAK No. 31 Tentang Akuntansi Perbankan).

Berdasarkan beberapa pengertian di atas dapat disimpulkan bahwa yang dimaksud dengan bank adalah suatu badan usaha yang memberikan jasa finansial dalam menghimpun dana dari masyarakat baik dalam bentuk simpanan atau bentuk lainnya dan disalurkan kembali kepada masyarakat yang membutuhkan dana serta berfungsi memperlancar lalu lintas pembayaran dengan tujuan mensejahterakan kehidupan rakyat banyak.

a. Jenis - Jenis Bank

Jenis bank jika dilihat dari segi operasionalnya terbagi dalam dua kelompok (Kasmir, 2008, hlm. 40) :

1) Bank Konvensional

Bank konvensional menurut Undang - Undang No. 21 Tahun

2008 adalah bank yang menjalankan kegiatan usahanya secara konvensional dan berdasarkan jenisnya terdiri atas bank umum 
konvensional dan bank perkreditan rakyat (Undang - Undang No. 21 Tahun 2008).

Definisi kata "konvensional" berdasarkan Kamus Umum Bahasa Indonesia adalah "menurut apa yang sudah menjadi kebiasaan". Sementara itu, menurut Kamus Besar Bahasa Indonesia (KBBI) adalah "berdasarkan kesepakatan umum" seperti adat, kebiasaan, kelaziman (www.kbbi.co.id). Berdasarkan definisi tersebut, bank konvensional merupakan bank yang dalam kegiatan usahanya menggunakan sistem mekanisme bunga, karena sistem mekanisme bunga telah digunakan sejak dahulu dan telah menjadi kebiasaan serta dipakai-secara meluas dibandingkan dengan sistem mekanisme bagi hasil.

2) Bank Syariah

Menurut Undang - Undang No. 21 Tahun 2008 tentang perbankan syariah yang dimaksud dengan bank Syariah adalah bank yang menjalankan kegiatan usahanya berdasarkan prinsip syariah dan menurut jenisnya terdiri atas Bank Umum Syariah dan Bank Pembiayaan Rakyat Syariah (Undang - Undang No. 21 Tahun 2008).

Bank syariah menurut Heri Sudarsono dalam bukunya yang berjudul bank dan lembaga keuangan syariah adalah lembaga keuangan yang dalam usaha pokoknya memberikan pembiayaan dan jasa-jasa keuangan lain dalam lalu lintas pembayaran serta peredaran uang yang beroperasi berdasarkan dengan prinsip-ptinsip syariah Islam (Sudarsono, 2008, hlm. 27).

Menurut Zainuddin Ali bank syariah adalah suatu lembaga keuangan yang berfungsi sebagai perantara bagi pihak yang berkelebihan dana dengan pihak yang kekurangan dana untuk kegiatan usaha dan kegiatan lainnya sesuai dengan hukum Islam (Ali, 2008, hlm. 1). Selain itu, bank syariah biasa disebut Islamic banking atau interest fee banking, yaitu suatu sistem perbankan dalam pelaksanaan operasional tidak menggunakan sistem bunga (riba), spekulasi (maisir), dan ketidakpastian atau ketidakjelasan (gharar) (Ali, 2008, hlm. 1).

Berdasarkan beberapa pengertian diatas dapat disimpulkan bahwa yang dimaksud dengan bank syariah adalah bank yang dalam operasionalnya baik menghimpun dana dari masyarakat maupun menyalurkannya kembali kepada masyarakat dengan berupa pembiayaaan dengan sistem bagi hasil yang berdasarkan ketentuan ketentuan syariat Islam antara lain tidak menggunakan sistem bunga (riba), spekulasi (maisir), dan ketidakpastian atau ketidakjelasan (gharar). 


\section{Konsep Inflasi}

Inflasi secara umum dapat diartikan sebagai kenaikan harga barang secara terus menerus yang disebabkan oleh berbagai faktor antara lain stabilitas politik, keamanan negara, spekulasi, paceklik dan lainnya. Inflasi merupakan kenaikan rata-rata semua tingkat harga yang cenderung terus-menerus dan berkepanjangan (Kasmir, 2010, hlm. 202).

Menurut Boediono pengertian inflasi adalah kecenderungan melonjaknya harga barang-barang pokok secara terus-menerus sedangkan definisi inflasi menurut para ekonom modern adalah meningkatnya jumlah uang yang harus dibayarkan (nilai unit penghitungan moneter) yang menyeluruh terhadap barang barang/komoditas/jasa (Karim, 2017, hlm. 135).

Inflasi menurut Bank Indonesia adalah naiknya harga-harga barang pokok secara umum dan terus menerus. Disebut inflasi apabila kenaikan itu meluas (atau mengakibatkan kenaikan harga) pada barang lainnya (www.bi.go.id).

Dari beberapa pengertian diatas dapat disimpulkan bahwa yang dimaksud dengan inflasi adalah kenaikan harga - harga barang umum secara signifikan yang menyebabkan turunnya nilai uang dalam suatu periode tertentu, kenaikan harga-harga barang umum tersebut akan mempengaruhi harga barang lainnya.

\section{Konsep Profitabilitas}

Rasio Profitabilitas menunjukkan kemampuan suatu bank untuk menghasilkan laba selama periode tertentu. Kemampuan bank untuk menghasilkan laba dalam kegiatan operasionalnya merupakan fokus utama dalam penilaian prestasi bank karena profitabilitas selain merupakan indikator kemampuan bank menjalankan kewajiban juga merupakan cerminan dalam penciptaan nilai bank yang menunjukkan prospek usahanya di masa yang akan datang.

Rasio profitabilitas dalam hal ini, menggambarkan kemampuan bank dalam meningkatkan profit melalui semua kemampuan dan sumber yang ada sehingga dapat diketahui tingkat efisiensi manajemen dalam memperoleh keuntungan yang dicapai oleh bank tersebut. Rasio ini juga memberikan ukuran tingkat efektivitas manajemen suatu perusahaan. Efisiensi sebuah usaha baru dapat diketahui setelah membandingkan laba yang diperoleh dengan aktiva atau modal yang menghasilkan laba tersebut.

Rasio profitabilitas menurut Kasmir dalam bukunya yang berjudul Analisis Laporan Keuangan merupakan rasio untuk menilai kemampuan perusahaan dalam mencari keuntungan (Kasmir, 2010, hlm. 169).

Menurut Wasis dalam Eva Sri Wahyuni rasio profitabilitas dipergunakan untuk mengukur tingkat keberhasilan manajemen 
perusahaan secara keseluruhan (Wahyuni, 2016, hlm. 24). Selain itu, menurut Malayu S.P. Hasibuan profitabilitas perbankan adalah suatu kondisi yang menggambarkan kesanggupan atau kemampuan bank dalam mendapatkan laba (Hasibuan, 2017, hlm. 53).

Jadi, dapat disimpulkan bahwa yang dimaksud dengan rasio profitabilitas adalah suatu ukuran dalam persentase yang digunakan untuk menilai sejauh mana perusahaan mampu menghasilkan laba dengan menggunakan sumber daya yang ada didalam perusahaan itu sendiri.

Dalam penelitian ini peneliti hanya menggunakan rasio profitabilitas yang diproksikan dengan Return on Asset. Return on Asset (ROA) merupakan rasio yang digunakan untuk mengukur kemampuan manajemen bank dalam memperoleh laba (Muhammad, 2005, hlm. 262). Return on Asset (ROA) digunakan untuk mengukur profitabilitas bank karena Bank Indonesia sebagai pembina dan pengawas perbankan lebih mengutamakan nilai profitabilitas suatu bank, diukur dengan aset yang dananya sebagian besar dari simpanan masyarakat.

Return on Asset (ROA) merupakan rasio yang menunjukkan hasil (return) atas jumlah aktiva yang digunakan dalam perusahaan (Kasmir, 2010, hlm. 202). Return on Asset (ROA) juga merupakan suatu ukuran tentang efektivitas manajemen dalam mengelola investasinya. Hasil pengembalian investasi menunjukkan produktivitas dari seluruh dana perusahaan, baik modal pinjaman maupun modal sendiri. Semakin rendah rasio ROA, semakin kurang baik, demikian pula sebaliknya. Artinya ROA digunakan untuk mengukur efektivitas dari keseluruhan operasional perusahaan. Untuk mencari Return on Asset dapat dirumuskan sebagai berikut (Muhardi dan Wenner, 2013, hlm. 60):

$$
\mathrm{ROA}=\frac{\text { Laba Bersih }}{\text { Total Aset }} \times 100 \%
$$

Bank Indonesia menilai kondisi profitabilitas perbankan di Indonesia didasarkan pada dua indikator yaitu Return on Asset (ROA) atau tingkat pengembalian asset Suatu bank dapat dimasukkan ke dalam klasifikasi sehat apabila rasio tingkat pengembalian atau Return on Asset (ROA) mencapai sekurang-kurangnya 1,2\% (Muhardi dan Wenner. 2013, hlm. 60).

\section{METODE PENELITIAN}

Penelitian ini merupakan penelitian asosiatif yang bertujuan untuk mengetahui pengaruh ataupun juga hubungan antara dua variabel atau lebih (Sugiyono, 2003 hlm. 11). Penelitian ini menggunakan pendekatan kuantitatif, yaitu penelitian yang hasil penelitiannya disajikan dalam bentuk deskriptif dengan menggunakan angka-angka statistik (Sugiyono, 2003 hlm. 14). 


\section{Definisi Oprasional}

Tabel 1 Devinisi Operasional

\begin{tabular}{|c|c|c|c|}
\hline Variabel & $\begin{array}{c}\text { Nama } \\
\text { Variabel }\end{array}$ & Definisi & Pernyataan \\
\hline Dependen & $\begin{array}{l}\text { ROA } \\
\text { Bank }\end{array}$ & $\begin{array}{l}\text { adalah salah satu dari rasio } \\
\text { profitabilitas yang dihitung } \\
\text { untuk mengukur } \\
\text { efektivitas bank dalam } \\
\text { menghasilkan laba dengan } \\
\text { memanfaatkan total aset } \\
\text { yang dimiliki. }\end{array}$ & $\begin{array}{l}\text { Muhardi, } \\
\text { Wenner R. } \\
\text { (2013). Analisis } \\
\text { Laporan } \\
\text { Keuangan, } \\
\text { Proyeksi dan } \\
\text { Valuasi Saham. } \\
\text { Salemba Empat. } \\
\text { Jakarta. } 64\end{array}$ \\
\hline Independen & $\begin{array}{c}\text { Inflasi } \\
\text { Negara } \\
\text { Indonesia }\end{array}$ & $\begin{array}{l}\text { adalah meningkatnya } \\
\text { harga-harga secara umum } \\
\text { dan terus menerus. }\end{array}$ & $\begin{array}{l}\text { www.bank } \\
\text { indonesia.go.id }\end{array}$ \\
\hline
\end{tabular}

\section{Teknik Analisis Data}

Analisis data yang digunakan dalam penelitian ini adalah :

a. Profitabitas

Indikator yang digunakan untuk mengukur profitabiitas adalah Retrun On Asset dengan rumus sebagai berikut:

$$
\mathrm{ROA}=\frac{\text { Laba Bersih }}{\text { Total Aset }} X 100 \%
$$

b. Uji Asumsi Klasik

Sebelum melakukan analisis regresi, perlu dilakukan pengujian asumsi klasik terlebih dahulu, agar data sampel yang diolah benar-benar dapat mewakili populasi secara keseluruhan. Uji asumsi klasik dalam penelitian ini mencakup uji normalitas dan uji heterokedastisitas. Uji asumsi tersebut secara lebih jelas diuraikan sebagai berikut:

1) Uji Normalitas

Uji normalitas yang lebih kompleks dan lengkap sering juga disebut dengan uji kesesuaian model yang dimaksudkan untuk menguji apakah model yang diusulkan memiliki kesesuaian dengan data atau tidak (Riadi, 2016, hlm. 105).

Seperti diketahui bahwa uji t mengasumsikan bahwa nilai residual mengikuti distribusi normal. Kalau asumsi ini dilanggar maka uji statistik menjadi tidak valid untuk jumlah sampel kecil. Ada dua cara yang tepat untuk mendeteksi apakah residual 
berdistribusi normal atau tidak yaitu sebagai berikut (Ghozali, 2016, hlm. 154):

a) Analisis Grafik

Salah satu cara termudah untuk melihat normalitas residual adalah dengan melihat grafik histogram yang membandingkan antara data observasi dengan distribusi yang mendekati distribusi normal (Ghozali, 2016, hlm. 154). Pengujian normalitas dalam penelitian ini menggunakan diagram histogram dan grafik p-p plot untuk memprediksi apakah data berdistribusi normal atau tidak.

b) Analisis Statistik

Uji Normalitas dengan grafik dapat menyesatkan jika tidak hati-hati secara visual kelihatan normal, padahal secara statistik bisa sebaliknya. Oleh sebab itu, dianjurkan disamping uji grafik dilengkapi dengan uji statistik. Salah satu uji statistik yang dapat digunakan untuk menguji normalitas residual adalah uji statistik non-parametik Kolmogorov-Smirnov (K-S) pada alpha sebesar 5\%. Jika nilai signifikan dari pengujian KolmogorovSmirnov lebih besar dari 0,05 berarti data normal, jika tidak maka data tidak berdistribusi normal (Ghozali, 2016, hlm. 158).

2) Uji Heteroskedastisitas

Uji heteroskedastisitas bertujuan untuk menguji apakah dalam model regresi terjadi ketidaksamaan varian residual dari satu observasi dengan yang lain (Husein, 2013, hlm. 179). Berikut beberapa cara dalam mendeteksi adanya heterokedastisitas (Ghozali, 2016, hlm. 139) :

a) Metode Grafik Scatterplot

Jika terdapat pola tertentu pada grafik scatterplot seperti titik-titik yang membentuk pola teratur (bergelombang) maka terjadi heterokedastisitas. Jika tidak ada pola yang jelas dan titiktitik menyebar diatas dan dibawah angka 0 pada sumbu Y maka tidak terjadi heterokedastisitas.

b) Uji Glejser

Uji glejser mengusulkan untuk meregresi nilai absolut residual terhadap variabel independen. Kriteria terjadinya heteroskedastisitas dalam suatu model regresi adalah jika signifikansinya $<0,05$, yang berarti bahwa apabila signifikansinya $>0,05$ penelitian dapat dilanjutkan.

c. Uji Hipotesis

1. Uji Signifikan Parameter Individual (Uji t) 
Uji t digunakan untuk menunjukkan seberapa jauh pengaruh satu variabel penjelas/independen secara individual dalam menerangkan variasi dependen (Ghozali, 2016, hlm. 97). Uji ini dilakukan dengan :

a) Jika $t_{\text {tabel }}>t_{\text {hitung, maka variabel independen tidak berpengaruh }}$ terhadap variabel dependen.

b) Jika $t_{\text {tabel }}<t_{\text {hitung, maka variabel independen berpengaruh }}$ signifikan terhadap variabel dependen.

Pengujian juga dapat dilakukan dengan melalui pengamatan nilai signifikansi t pada tingkat a yang digunakan (penelitian ini menggunakam tingkat a sebesar 0.05 atau 5\%). Analisis ini didasarkan pada perbandingan antara nilai signifikansi t dengan nilai signifikansi 0.05 , dimana syarat-syarat sebagai berikut:

a) Jika signifikansi $t<0.05$ maka variabel independen berpengaruh positif terhadap variabel dependen (Ho ditolak, Ha diterima).

b) Jika signifikansi $\mathrm{t}>0.05$ maka variabel independen tidak berpengaruh positif terhadap variabel dependen (Ho diterima, Ha ditolak).

d. Analisis Regresi Linear Sederhana

Teknik analisis data dalam penelitian ini menggunakan regresi linear sederhana. Analisis regresi linear sederhana digunakan untuk menentukan pengaruh variabel dependen (variabel bebas) terhadap satu variabel independen (variabel terikat) atau untuk membuktikan ada atau tidaknya hubungan fungsional antara variabel bebas (X) dengan sebuah variabel terikat (Y). Penelitian ini menggunakan teknik Analisis Regresi Linear Sederhana dengan menggunakan program Microsoft Office Excel. Variabel dependen adalah Return on Asset (ROA) sedangkan variabel independen meliputi inflasi. Model persamaan linear sederhana adalah sebagai berikut:

$\hat{Y}=\alpha+\beta x$

Keterangan :

$\hat{Y}$

: Return on Asset (ROA)

$\alpha \quad$ : Koefisien konstanta

$\beta \quad$ : Koefisien regresi

$x \quad$ : Inflasi

\section{HASIL DAN PEMBAHASAN}

\section{Hasil}

a. Profitabilitas

1) PT. Bank Rakyat Indonesia Syariah.(Persero).Tbk 
Return on Asset (ROA) merupakan rasio yang digunakan untuk mengukur kemampuan manajemen bank dalam memperoleh laba dengan membandingkan antara laba bersih dengan total aset yang dimiliki oleh bank. Berikut adalah tabel Retrun On Asset PT. Bank Rakyat Indonesia Syariah. (Persero).Tbk.

Tabel 2 Retrun On Asset

PT. Bank Rakyat Indonesia Syariah

\begin{tabular}{|c|c|c|c|c|c|c|}
\hline No & Tahun & Bulan & Inflasi(\%) & $\begin{array}{c}\text { Laba Bersih } \\
\text { (Dalam Jutaan } \\
\text { Rupiah) }\end{array}$ & $\begin{array}{c}\text { Total Aset } \\
\text { (Dalam Jutaan } \\
\text { Rupiah) }\end{array}$ & $\operatorname{ROA}(\%)$ \\
\hline 1 & 2015 & Januari & 6,96 & 10.840 & 20.218 .457 & 0,053614378 \\
\hline 2 & & Februari & 6,29 & 20.174 & 20.442 .685 & 0,098685667 \\
\hline 3 & & Maret & 6,38 & 28.380 & 20.568 .270 & $\mathbf{0 , 1 3 7 9 7 9 5 1 9}$ \\
\hline 4 & & April & 6,79 & 38.523 & 21.444 .991 & 0,179636354 \\
\hline 5 & & Mei & 7,15 & 53.815 & 21.806 .470 & 0,246784555 \\
\hline 6 & & Juni & 7,26 & 62.694 & 21.627 .334 & 0,289883164 \\
\hline 7 & & Juli & 7,26 & 80.058 & 22.432 .426 & 0,356885163 \\
\hline 8 & & Agustus & 7,18 & 94.461 & 22.154 .179 & 0,426380052 \\
\hline 9 & & September & 6,83 & 95.785 & 22.814 .816 & 0,419836829 \\
\hline 10 & & Oktober & 6,83 & 111.247 & 23.052 .666 & 0,48257759 \\
\hline 11 & & Nopember & 4,89 & 119.746 & 23.090 .581 & 0,518592408 \\
\hline 12 & & Desember & 3,35 & 117.897 & 24.239 .170 & $\mathbf{0 , 4 8 6 3 9 0 4 1 7}$ \\
\hline 13 & 2016 & Januari & 4,14 & 18.493 & 23.143 .028 & 0,079907435 \\
\hline 14 & & Februari & 4,42 & 26.045 & 23.542 .689 & 0,110628824 \\
\hline 15 & & Maret & 4,45 & 45.615 & 24.268 .704 & $\mathbf{0 , 1 8 7 9 5 8 1 2 1}$ \\
\hline 16 & & April & 3,6 & 70.972 & 24.431 .929 & 0,290488729 \\
\hline 17 & & Mei & 3,33 & 93.814 & 24.909 .965 & 0,376612332 \\
\hline 18 & & Juni & 3,45 & 100.455 & 25.051 .562 & 0,40099296 \\
\hline 19 & & Juli & 3,21 & 109.714 & 24.929 .076 & 0,440104559 \\
\hline 20 & & Agustus & 2,79 & 126.822 & 25.339 .654 & 0,500488286 \\
\hline 21 & & September & 3,07 & 128.201 & 25.568 .485 & 0,50140241 \\
\hline 22 & & Oktober & 3,31 & 143.351 & 25.748 .441 & 0,55673662 \\
\hline 23 & & Nopember & 3,58 & 157.978 & 27.350 .530 & 0,577604895 \\
\hline 24 & & Desember & 3,02 & 170.642 & 27.693 .406 & 0,616182784 \\
\hline 25 & 2017 & Januari & 3,49 & 13.372 & 27.577 .027 & 0,048489636 \\
\hline 26 & & Februari & 3,83 & 29.274 & 27.756 .847 & 0,105465869 \\
\hline 27 & & Maret & 3,61 & 32.300 & 28.506 .856 & 0,113306076 \\
\hline 28 & & April & 4,17 & 45.151 & 28.641 .334 & $\mathbf{0 , 1 5 7 6 4 2 7 9 7}$ \\
\hline 29 & & Mei & 4,33 & 54.910 & 29.419 .625 & 0,186644119 \\
\hline 30 & & Juni & 4,37 & 70.060 & 29.910 .531 & 0,234231883 \\
\hline 31 & & Juli & 3,88 & 92.774 & 29.530 .559 & 0,314162695 \\
\hline 32 & & Agustus & 3,82 & 108.096 & 30.142 .743 & 0,35861368 \\
\hline 33 & & September & 3,72 & 122.895 & 30.422 .031 & 0,403967112 \\
\hline
\end{tabular}




\begin{tabular}{|l|l|c|c|c|c|c|}
34 & & Oktober & 3,58 & 142.925 & 30.458 .029 & $\mathbf{0 , 4 6 9 2 5 2 2 9 5}$ \\
\hline 35 & & Nopember & 3,3 & 168.286 & 30.688 .712 & $\mathbf{0 , 5 4 8 3 6 4 4 9 3}$ \\
\hline 36 & & Desember & 3,61 & 96.939 & 31.546 .275 & $\mathbf{0 , 3 0 7 2 9 1 4 3 1}$ \\
\hline 37 & 2018 & Januari & 3,25 & $(2.045)$ & 32.958 .028 & $\mathbf{0 , 0 0 6 2 0 4 8 6 2}$ \\
\hline 38 & & Februari & 3,18 & 14.071 & 35.047 .357 & $\mathbf{0 , 0 4 0 1 4 8 5 3 4}$ \\
\hline 39 & & Maret & 3,4 & 56.887 & 34.733 .951 & $\mathbf{0 , 1 6 3 7 7 9 2 3 7}$ \\
\hline 40 & & April & 3,41 & 77.516 & 35.607 .445 & $\mathbf{0 , 2 1 7 6 9 6 0 4 6}$ \\
\hline 41 & & Mei & 3,23 & 98.820 & 35.718 .394 & $\mathbf{0 , 2 7 6 6 6 4 1 7 5}$ \\
\hline 42 & & Juni & 3,12 & 125.177 & 36.140 .568 & $\mathbf{0 , 3 4 6 3 6 1 4 6 3}$ \\
\hline 43 & & Juli & 3,18 & 138.471 & 35.330 .370 & $\mathbf{0 , 3 9 1 9 3 1 9 2 7}$ \\
\hline 44 & & Agustus & 3,2 & 149.654 & 35.847 .727 & $\mathbf{0 , 4 1 7 4 7 1 3 7 8}$ \\
\hline 45 & & September & 2,88 & 154.708 & 36.177 .022 & $\mathbf{0 , 4 2 7 6 4 1 6 1 2}$ \\
\hline 46 & & Oktober & 3,16 & 94.075 & 35.961 .308 & $\mathbf{0 , 2 6 1 6 0 0 6 0 7}$ \\
\hline 47 & & Nopember & 3,23 & 126.818 & 36.242 .706 & $\mathbf{0 , 3 4 9 9 1 3 1 6 6}$ \\
\hline 48 & & Desember & 3,13 & 190.250 & 38.480 .749 & $\mathbf{0 , 4 9 4 4 0 3 0 5 9}$ \\
\hline
\end{tabular}

(Sumber : Data skunder yang dioleh peneliti)

2) PT. Bank Rakyat Indonesia.(Persero).Tbk'

Berikut adalah tabel Retrun On Asset PT. Bank Rakyat Indonesia. (Persero).Tbk.

Tabel 3 Retrun On Asset

PT. Bank Rakyat Indonesia

\begin{tabular}{|c|c|c|c|c|c|c|}
\hline No & Tahun & Bulan & Inflasi(\%) & $\begin{array}{c}\text { Laba Bersih } \\
\text { (Dalam Jutan } \\
\text { Rupiah) }\end{array}$ & $\begin{array}{c}\text { Total Aset } \\
\text { (Dalam Jutaan } \\
\text { Rupiah) }\end{array}$ & ROA(\%) \\
\hline 1 & 2015 & Januari & 6,96 & 2.011 .225 & 739.423 .863 & $\mathbf{0 , 2 7 1 9 9 8 9 3 1}$ \\
\hline 2 & & Februari & 6,29 & 3.929 .900 & 760.976 .673 & $\mathbf{0 , 5 1 6 4 2 8 4 4 5}$ \\
\hline 3 & & Maret & 6,38 & 3.929 .900 & 781.181 .119 & $\mathbf{0 , 5 0 3 0 7 1 5 5 5}$ \\
\hline 4 & & April & 6,79 & 6.560 .739 & 739.906 .648 & $\mathbf{0 , 8 8 6 6 9 8 2 1}$ \\
\hline 5 & & Mei & 7,15 & 7.288 .253 & 731.479 .524 & $\mathbf{0 , 9 9 6 3 7 1 4 3 1}$ \\
\hline 6 & & Juni & 7,26 & 11.674 .123 & 747.478 .357 & $\mathbf{1 , 5 6 1 8 0 0 8 0 5}$ \\
\hline 7 & & Juli & 7,26 & 13.028 .592 & 770.061 .037 & $\mathbf{1 , 6 9 1 8 9 0 8 2 1}$ \\
\hline 8 & & Agustus & 7,18 & 14.350 .245 & 765.047 .314 & $\mathbf{1 , 8 7 5 7 3 3 0 0 9}$ \\
\hline 9 & & September & 6,83 & 17.087 .571 & 775.815 .985 & $\mathbf{2 , 2 0 2 5 2 8 8 6 4}$ \\
\hline 10 & & Oktober & 6,83 & 19.996 .769 & 767.085 .573 & $\mathbf{2 , 6 0 6 8 4 9 8 3 6}$ \\
\hline 11 & & Nopember & 4,89 & 22.336 .164 & 791.576 .510 & $\mathbf{2 , 8 2 1 7 3 1 5 3 4}$ \\
\hline 12 & & Desember & 3,35 & 24.595 .463 & 849.413 .068 & $\mathbf{2 , 8 9 5 5 8 3 3 0 6}$ \\
\hline 13 & 2016 & Januari & 4,14 & 2.488 .513 & 831.314 .089 & $\mathbf{0 , 2 9 9 3 4 6 9 0 5}$ \\
\hline 14 & & Februari & 4,42 & 4.614 .914 & 835.865 .395 & $\mathbf{0 , 5 5 2 1 1 2 1 0 2}$ \\
\hline 15 & & Maret & 4,45 & 7.273 .457 & 832.091 .635 & $\mathbf{0 , 8 7 4 1 1 7 3 0 8}$ \\
\hline 16 & & April & 3,6 & 9.045 .449 & 817.279 .985 & $\mathbf{1 , 1 0 6 7 7 4 8 1}$ \\
\hline 17 & & Mei & 3,33 & 10.513 .519 & 825.414 .132 & $\mathbf{1 , 2 7 3 7 2 6 5 5 6}$ \\
\hline
\end{tabular}




\begin{tabular}{|c|c|c|c|c|c|c|}
\hline 18 & & Juni & 3,45 & 14.096 .367 & 873.740 .565 & 1,613335533 \\
\hline 19 & & Juli & 3,21 & 30.456 .113 & 871.188 .835 & 3,495925542 \\
\hline 20 & & Agustus & 2,79 & 32.681 .318 & 871.671 .241 & 3,749271109 \\
\hline 21 & & September & 3,07 & 35.114 .860 & 894.359 .725 & 3,926256854 \\
\hline 22 & & Oktober & 3,31 & 36.998 .499 & 907.153 .818 & 4,078525413 \\
\hline 23 & & Nopember & 3,58 & 38.167 .792 & 926.015.219 & 4,121724051 \\
\hline 24 & & Desember & 3,02 & 40.817 .815 & 964.000 .690 & 4,234210144 \\
\hline 25 & 2017 & Januari & 3,49 & 2.478 .125 & 944.115 .786 & 0,262481047 \\
\hline 26 & & Februari & 3,83 & 4.410 .876 & 944.874 .984 & 0,466821122 \\
\hline 27 & & Maret & 3,61 & 7.468 .036 & 954.176 .142 & 0,78266849 \\
\hline 28 & & April & 4,17 & 8.865 .208 & 944.671 .082 & $\mathbf{0 , 9 3 8 4 4 3 8 8 5}$ \\
\hline 29 & & Mei & 4,33 & 10.696 .317 & 987.315 .689 & $\mathbf{1 , 0 8 3 3 7 3 5 4 7}$ \\
\hline 30 & & Juni & 4,37 & 13.916 .803 & 983.518 .187 & 1,4150021 \\
\hline 31 & & Juli & 3,88 & 15.724 .979 & 967.910 .998 & 1,624630677 \\
\hline 32 & & Agustus & 3,82 & 18.524 .518 & 997.529 .163 & 1,857040244 \\
\hline 33 & & September & 3,72 & 21.535 .489 & 993.100 .820 & 2,16850984 \\
\hline 34 & & Oktober & 3,58 & 23.647 .471 & 994.000 .867 & 2,379019152 \\
\hline 35 & & Nopember & 3,3 & 23.190 .701 & 1.018 .264 .422 & 2,277473365 \\
\hline 36 & & Desember & 3,61 & 30.067 .798 & 1.076 .438 .066 & 2,793267811 \\
\hline 37 & 2018 & Januari & 3,25 & 2.127 .703 & 1.050 .804 .077 & $\mathbf{0 , 2 0 2 4 8 3 3 2 2}$ \\
\hline 38 & & Februari & 3,18 & 6.080 .842 & 1.050 .188 .240 & 0,579024004 \\
\hline 39 & & Maret & 3,4 & 6.026 .564 & 1.064 .732 .202 & $\mathbf{0 , 5 6 6 0 1 6 8 8 1}$ \\
\hline 40 & & April & 3,41 & 6.955 .535 & 1.055 .022 .048 & $\mathbf{0 , 6 5 9 2 7 8 6 3 9}$ \\
\hline 41 & & Mei & 3,23 & 8.929 .249 & 1.080 .207 .583 & 0,826623432 \\
\hline 42 & & Juni & 3,12 & 10.808 .492 & 1.097 .368 .442 & 0,984946494 \\
\hline 43 & & Juli & 3,18 & 13.324 .291 & 1.086 .497 .477 & 1,226352687 \\
\hline 44 & & Agustus & 3,2 & 16.031 .207 & 1.113 .552 .553 & 1,439645301 \\
\hline 45 & & September & 2,88 & 18.984 .257 & 1.125 .400 .727 & $\mathbf{1 , 6 8 6 8 8 8 6 3 8}$ \\
\hline 46 & & Oktober & 3,16 & 21.717 .417 & 1.157 .729 .110 & 1,875863431 \\
\hline 47 & & Nopember & 3,23 & 25.503 .876 & 1.172 .171 .960 & 2,175779397 \\
\hline 48 & & Desember & 3,13 & 28.594 .479 & 1.234 .200 .039 & 2,316843145 \\
\hline
\end{tabular}

(Sumber : Data skunder yang dioleh peneliti)

b. Uji Asumsi klasik

Sebelum melakukan analisis regresi, perlu dilakukan pengujian asumsi klasik terlebih dahulu, agar data sampel yang diolah benar-benar dapat mewakili populasi secara keseluruhan dan juga dapat digunakan untuk membuat model persamaan regresi yang tepat. Uji asumsi klasik dalam penelitian ini mencakup uji normalitas dan uji heterokedastisitas. Berikut adalah hasil dari pada uji asumsi klasik :

1) Uji Normalitas

a) Analisis grafik 
Cara untuk mendeteksi apakah residual data berdistribusi normal ataukah tidak adalah dengan melihat grafik normal probability plot, apabila pada grafik normal probability plot tampak bahwa titik-titik menyebar berhimpit disekitar garis diagonal dan searah mengikuti garis diagonal maka hal ini dapat disimpulkan bahwa residual data memiliki distribusi normal, atau data memenuhi asumsi klasik normalitas.

\section{Gambar 2}

Grafik Normal Probability Plot

PT. Bank Rakyat Indonesia Syariah(Persero). Tbk

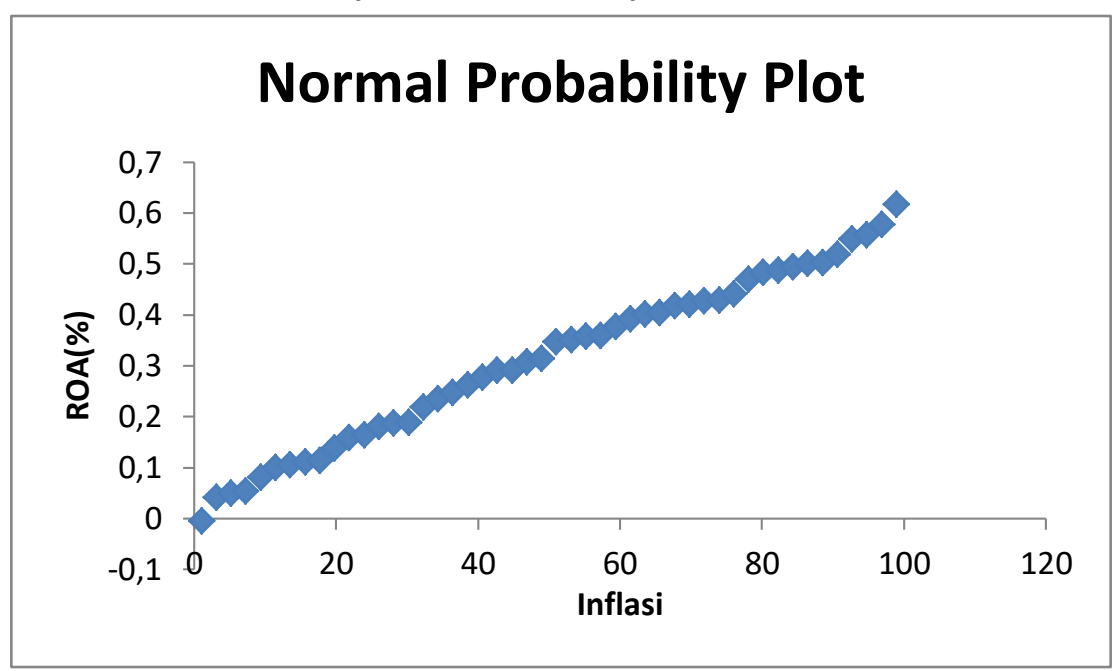

Gambar 3

Grafik Normal Probability Plot

PT. Bank Rakyat Indonesia(Persero). Tbk

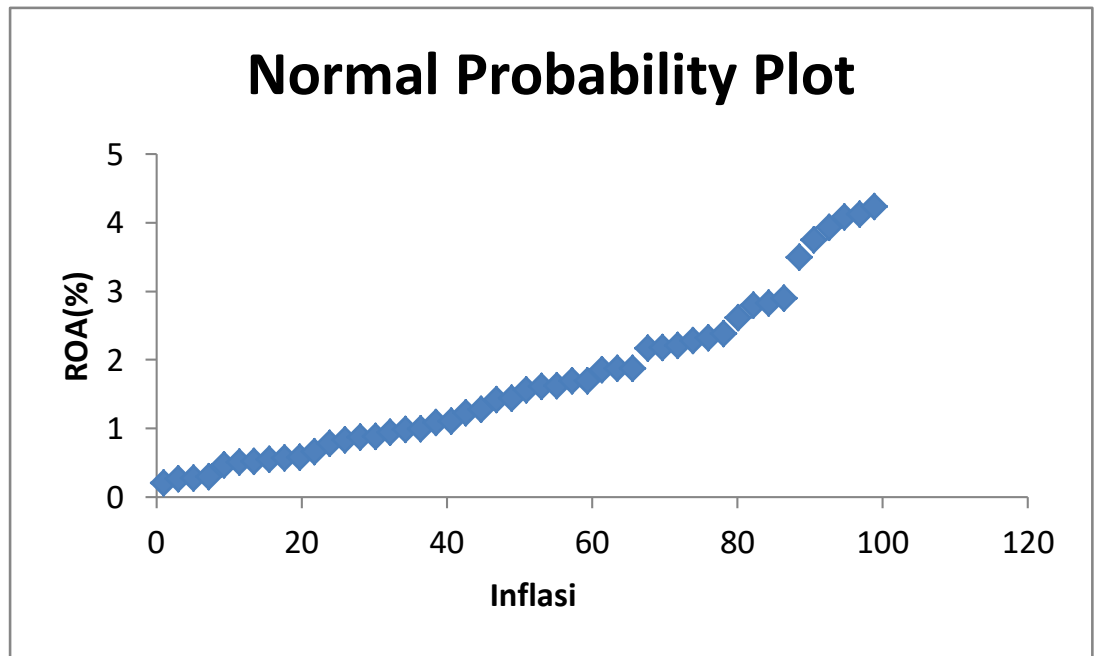

Berdasarkan gambar 2 dam 3 grafik normal probability plot PT. Bank Rakyat Indonesia Syariah dan PT. Bank Rakyat Indonesia di atas dapat diketahui bahwa titik-titik menyebar berhimpit disekitar garis diagonal dan searah mengikuti garis 
diagonal maka hal ini dapat disimpulkan bahwa residual data memiliki distribusi normal, atau data memenuhi asumsi klasik normalitas.

b) Analisis Statistik

Cara untuk mendeteksi apakah residual data berdistribusi normal ataukah tidak dengan melakukan uji statistik One Kolmogrov-Smirnov Test. Pada uji statistik One-KolmogrovSmirnov Test jika didapat nilai signifikasi > 0.05, maka dapat disimpulkan bahwa data terdistribusi normal.

Tabel 4

Uji One-Kolmogrov-Smirnov Test

PT. Bank Rakyat Indonesia Syariah(Persero). Tbk

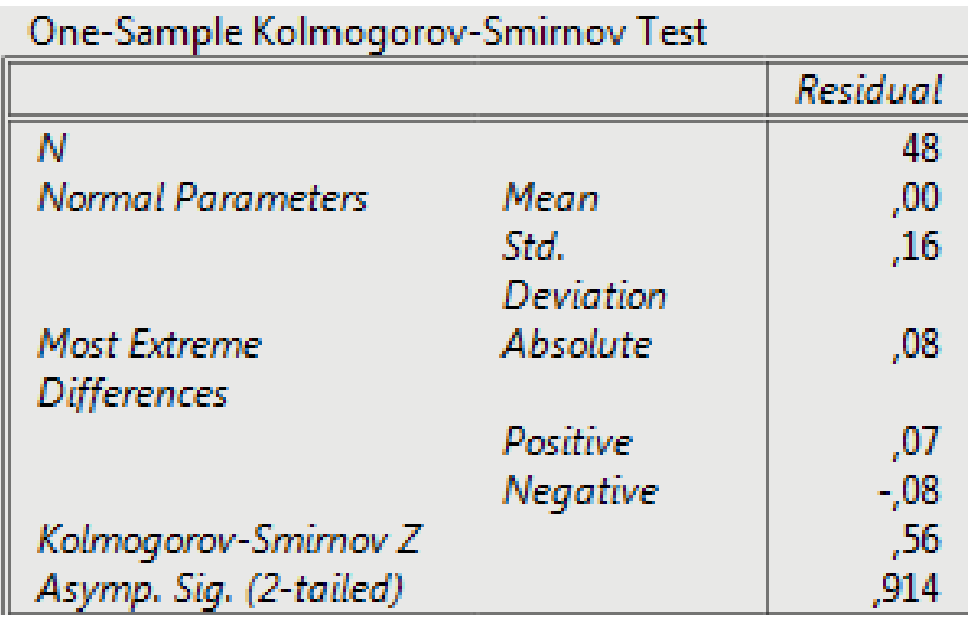

Tabel 5

Uji One-Kolmogrov-Smirnov Test

PT. Bank Rakyat Indonesia(Persero). Tbk

One-Sample Kolmogorov-Smirnov Test

\begin{tabular}{|c|c|c|}
\hline & & Residual \\
\hline$N$ & & 48 \\
\hline Normal Parameters & Mean &, 00 \\
\hline & $\begin{array}{l}\text { Std. } \\
\text { Deviation }\end{array}$ & 1,10 \\
\hline Most Extreme & Absolute & 11 \\
\hline & $\begin{array}{l}\text { Positive } \\
\text { Negative }\end{array}$ & $\begin{array}{r}11 \\
-, 07\end{array}$ \\
\hline $\begin{array}{l}\text { Kolmogorov-Smirnov Z } \\
\text { Asymp. Sig. (2-tailed) }\end{array}$ & & (59 \\
\hline
\end{tabular}

Berdasarkan tabel 3 dan 4 uji One-Kolmogrov-Smirnov PT. Bank Rakyat Indonesia Syariah dan PT. Bank Rakyat Indonesia di atas dapat diketahui bahwa nilai kolmogrov-Smirnov pada PT. 
Bank Rakyat Indonesia Syariah sebesar 0,914 lebih besar dari 0,05, sedangkan pada PT. Bank Rakyat Indonesia sebesar 0,560 lebih besar dari 0,05 maka dapat disimpulkan bahwa kedua data tersebut memenuhi asumsi klasik.

2) Uji Heteroskedastis

a) Metode Grafik Scatterplot

Uji heteroskedastisitas bertujuan untuk menguji apakah dalam model regresi terjadi ketidaksamaan varian residual dari satu observasi dengan yang lain. Salah satu cara untuk mengetahui apakah terjadi heteroskedastis ataukah tidak adalah dengan melihat grafik scatterplot. Jika terdapat pola tertentu pada grafik scatterplot seperti titik-titik yang membentuk pola teratur (bergelombang) maka terjadi heteroskedastisitas. Jika tidak ada pola yang jelas dan titik-titik menyebar diatas dan dibawah angka 0 pada sumbu Y maka tidak terjadi heterokedastisitas.

Gambar 4

Grafik Scatterplot

PT. Bank Rakyat Indonesia Syariah(Persero). Tbk

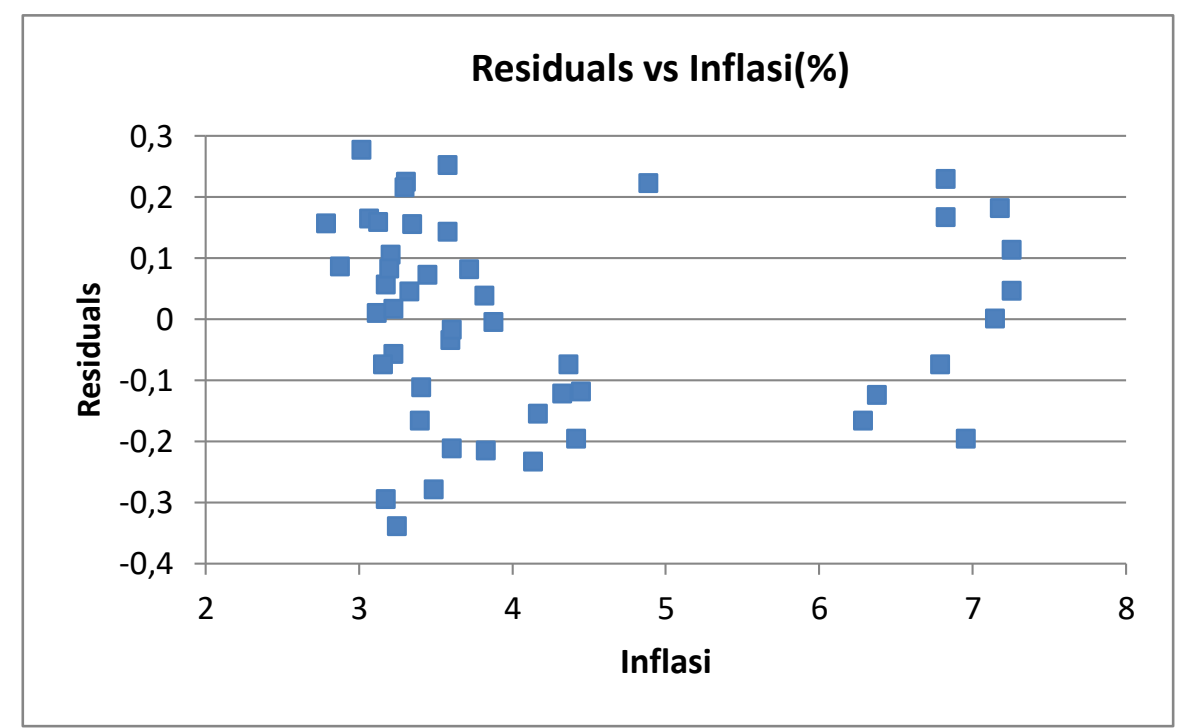




\section{Gambar 5}

Grafik Scatterplot

PT. Bank Rakyat Indonesia(Persero). Tbk

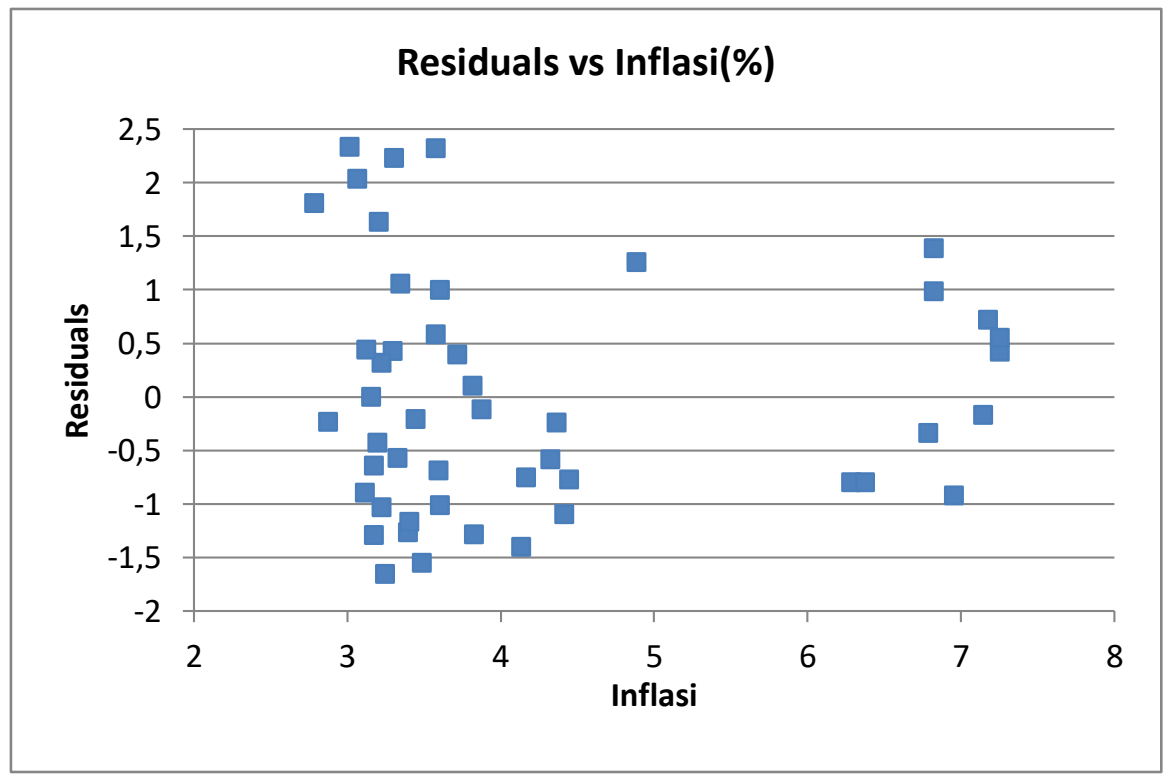

Berdasarkan tampilan grafik Scatterplot pada Gambar 4 dan $5 \mathrm{di}$ atas dapat diketahui bahwa titik-titik menyebar secara acak diatas dan dibawah angka 0 pada sumbu Y. Hal itu dapat menunjukkan bahwa persamaan regresi kedua data tersebut tidak mengalami gejala heteroskedastisitas.

b) Uji Glejser

Uji glejser mengusulkan untuk meregresi nilai absolut residual terhadap variabel independen Kriteria terjadinya heteroskedastisitas dalam suatu model regresi adalah jika signifikansinya $<0,05$, yang berarti bahwa apabila signifikansinya $>0,05$ penelitian dapat dilanjutkan.

Tabel 6

Uji Glejser

PT. Bank Rakyat Indonesia Syariah(Persero). Tbk

\begin{tabular}{|c|r|r|r|r|r|r|}
\hline & Coefficients & $\begin{array}{c}\text { Standard } \\
\text { Error }\end{array}$ & LCL & UCL & \multicolumn{1}{c|}{ Stat } & \multicolumn{1}{c|}{$p$-value } \\
\hline Intercept & 0,1467 & 0,0389 & 0,0684 & 0,2250 & 3,7731 & 0,0005 \\
\hline Inflasi(\%) & $-0,0023$ & 0,0087 & $-0,0198$ & 0,0152 & $-0,2663$ & $\mathbf{0 , 7 9 1 2}$ \\
\hline
\end{tabular}


Tabel 7

Uji Glejser

PT. Bank Rakyat Indonesia(Persero). Tbk

\begin{tabular}{|l|r|r|r|r|r|r|}
\hline & Coefficients & $\begin{array}{c}\text { Standard } \\
\text { Error }\end{array}$ & LCL & UCL & $t$ Stat & $p$-value \\
\hline Intercept & 1,3124 & 0,2678 & 0,7733 & 1,8515 & 4,8999 & $1,2289 \mathrm{E}-5$ \\
\hline Inflasi(\%) & $-0,0936$ & 0,0598 & $-0,2140$ & 0,0268 & $-1,5650$ & $\mathbf{0 , 1 2 4 4}$ \\
\hline
\end{tabular}

Berdasarkan tabel 5 dan 6 uji glejser pada PT. Bank Rakyat Indonesia Syariah dan PT. Bank Rakyat Indonesia di atas dapat diketahui bahwa nilai p-value $(0,7912)$ pada PT. Bank Rakyat Indonesia Syariah lebih besar dari 0,05 sedangkan pada PT. Bank Rakyat Indonesia maka dapat disimpulkan bahwa kedua data tersebut tidak terjadi heteroskedastisitas, maka penelitian ini dapat dilanjutkan.

c. Uji Hipotesis

1) Uji t

Uji t digunakan untuk menunjukkan seberapa jauh pengaruh satu variabel penjelas/independen secara individual dalam menerangkan variasi dependen.

\section{Tabel 8}

\section{Uji t}

PT. Bank Rakyat Indonesia Syariah(Persero). Tbk

\begin{tabular}{|l|r|r|r|r|r|r|}
\hline & Coefficients & $\begin{array}{c}\text { Standard } \\
\text { Error }\end{array}$ & LCL & UCL & \multicolumn{1}{c|}{ t Stat } & \multicolumn{1}{c|}{$p$-value } \\
\hline Intercept & 0,4072 & 0,0741 & 0,2581 & 0,5563 & 5,4967 & $1,6330 \mathrm{E}-6$ \\
\hline Inflasi(\%) & $-0,0225$ & 0,0165 & $-0,0558$ & 0,0108 & $-1,3598$ & 0,1805 \\
\hline
\end{tabular}

Berdasarkan hasil uji t pada tabel 7 PT. Bank Rakyat Indonesia Syariah di atas menunjukan nilai $t_{\text {Hitung }}$ sebesar $(-1,3598)$ lebih kecil dari nilai $\mathrm{t}_{\text {tabel }}$ sebesar $(1,6786)$ maka $\mathrm{H}_{0}$ diterima yang berarti, Inflasi tidak berpengaruh positif terhadap ROA bank syariah. Nilai $p$-value sebesar 0,1805 lebih besar dari 0,05 dan nilai coefficients tingkat inflasi sebesar $(-0,0225)$ menunjukan angka negatif, hal ini menunjukan bahwa inflasi memiliki pengaruh negatif dan tidak signifikan terhadap ROA.

\section{Tabel 9}

Uji $\mathbf{t}$

PT. Bank Rakyat Indonesia(Persero). Tbk

\begin{tabular}{|l|r|r|c|c|c|c|}
\hline & Coefficients & $\begin{array}{c}\text { Standard } \\
\text { Error }\end{array}$ & LCL & UCL & t Stat & $p$-value \\
\hline Intercept & 2,4378 & 0,5032 & 1,4248 & 3,4507 & 4,8441 & $1,4805 \mathrm{E}-5$ \\
\hline
\end{tabular}




\begin{tabular}{|l|r|r|r|r|r|r|}
\hline Inflasi(\%) & $-0,1781$ & 0,1124 & $-0,4043$ & 0,0481 & $-1,5848$ & 0,1199 \\
\hline
\end{tabular}

Berdasarkan hasil uji t pada tabel 8 PT. Bank Rakyat Indonesia Syariah di atas menunjukan nilai $t_{\text {Hitung }}$ sebesar $(-1,5848)$ lebih kecil dari nilai $\mathrm{t}_{\text {tabel }}(1,6786)$ maka $\mathrm{H}_{0}$ diterima yang berarti, Inflasi tidak berpengaruh positif terhadap ROA bank konvensional. Nilai $p$ - value sebesar 0,1199 lebih besar dari 0,05 dan nilai coefficients tingkat inflasi sebesar $(-0,1781)$ menunjukan angka negatif, hal ini menunjukan bahwa inflasi memiliki pengaruh negatif dan tidak signifikan terhadap ROA.

d. Analisis Regresi Linear Sederhana

Analisis regresi linear sederhana digunakan untuk menentukan pengaruh variabel dependen (variabel bebas) terhadap satu variabel independen (variabel terikat) atau untuk membuktikan ada atau tidaknya hubungan fungsional antara variabel bebas $(\mathrm{X})$ inflasi dengan sebuah variabel terikat (Y) ROA.

\section{Tabel 10}

Analisis Regresi Linear Sederhana

PT. Bank Rakyat Indonesia Syariah(Persero). Tbk

\begin{tabular}{|l|r|r|r|r|r|r|}
\hline & Coefficients & $\begin{array}{c}\text { Standard } \\
\text { Error }\end{array}$ & \multicolumn{1}{c|}{ LCL } & UCL & \multicolumn{1}{c|}{ t Stat } & \multicolumn{1}{c|}{$p$-value } \\
\hline Intercept & 0,4072 & 0,0741 & 0,2581 & 0,5563 & 5,4967 & $1,6330 \mathrm{E}-6$ \\
\hline Inflasi(\%) & $-0,0225$ & 0,0165 & $-0,0558$ & 0,0108 & $-1,3598$ & 0,1805 \\
\hline
\end{tabular}

Berdasarkan tabel 9 hasil analisis regresi linear sederhana ROA pada PT. Bank Rakyat Indonesia Syariah dan inflasi, diperoleh nilai Coefficients yang dapat digunakan untuk membuat persamaan regresi linear sederhana sebagai berikut :

$$
\begin{aligned}
& \hat{Y}=\alpha+\beta x \\
& \widehat{Y}=0,4072-0,0225 x
\end{aligned}
$$

Keterangan :

$\begin{array}{ll}\hat{Y} & : \text { Return on Asset (ROA) } \\ \alpha & : \text { Koefisien konstanta } \\ \beta & : \text { Koefisien regresi } \\ x & : \text { Inflasi }\end{array}$

Tabel 11

Analisis Regresi Linear Sederhana

PT. Bank Rakyat Indonesia(Persero). Tbk

\begin{tabular}{|l|r|r|r|r|r|r|}
\hline & Coefficients & $\begin{array}{c}\text { Standard } \\
\text { Error }\end{array}$ & LCL & UCL & t Stat & \multicolumn{1}{c|}{$p$-value } \\
\hline Intercept & 2,4378 & 0,5032 & 1,4248 & 3,4507 & 4,8441 & $1,4805 \mathrm{E}-5$ \\
\hline Inflasi(\%) & $-0,1781$ & 0,1124 & $-0,4043$ & 0,0481 & $-1,5848$ & 0,1199 \\
\hline
\end{tabular}


Berdasarkan tabel 10 hasil analisis regresi linear sederhana ROA pada PT. Bank Rakyat Indonesia dan inflasi, diperoleh nilai Coefficients yang dapat digunakan untuk membuat persamaan regresi linear sederhana sebagai berikut :

$$
\begin{aligned}
& \hat{Y}=\alpha+\beta x \\
& \hat{Y}=2,4378-0,1781 x
\end{aligned}
$$

Keterangan :

$\begin{array}{ll}\hat{Y} & : \text { Return on Asset (ROA) } \\ \alpha & : \text { Koefisien konstanta } \\ \beta & : \text { Koefisien regresi } \\ x & : \text { Inflasi }\end{array}$

\section{Pembahasan}

Inflasi merupakan Salah satu faktor eksternal yang diduga berpengaruh terhadap profitabilitas bank syariah maupun bank konvensional. Inflasi adalah kemerosotan nilai mata uang (kertas) karena terlalu banyak beredar dan menyebabkan melambungnya harga barang barang (www.bi.go.id). Profitabilitas merupakan kemampuan suatu perusahaan untuk mendapatkan laba dalam suatu periode tertentu Kasmir, 2010, hlm. 34).

Penelitian ini bertujuan untuk menganalisis pengaruh inflasi terhadap profitabilitas pada bank syariah dan bank konvensional yang diproyeksikan dengan Return on Asset (ROA) periode tahun 2015-2018 (Studi Kasus PT. Bank Rakyat Indonesia Syariah.(Persero).Tbk dan PT. Bank Rakyat Indonesia (Persero).Tbk).

Hasil dalam penelitian ini menunjukkan bahwa variabel bebas tingkat inflasi memiliki pengaruh negatif dan tidak signifikan terhadap variabel terikat Retrun On Asset (ROA) pada PT. Bank Rakyat Indonesia Syariah.(Persero).Tbk dan PT. Bank Rakyat Indonesia (Persero).Tbk. Hal ini ditunjukan dari nilai $p$-value sebesar 0,1805 lebih besar dari 0,05 dan nilai $t_{\text {Hitung }}$ sebesar $(-1,3598)$ lebih kecil dari nilai $t_{\text {tabel }}$ sebesar 1,6786 pada PT. Bank Rakyat Indonesia Syariah.(Persero).Tbk maka dapat disimpulkan $\mathrm{H}_{0}$ diterima. Sedangkan pada PT. Bank Rakyat Indonesia (Persero).Tbk, nilai $p$-value sebesar 0,1199 lebih besar dari 0,05 dan nilai $\mathrm{t}_{\text {Hitung }}$ sebesar $(-1,5848)$ lebih kecil dari nilai $\mathrm{t}_{\text {tabel }}(1,6786)$ maka dapat disimpulkan $\mathrm{H}_{0}$ diterima.

Arah hubungan yang ditunjukkan dalam dua studi kasus penelitian ini adalah negatif. Hal ini menunjukkan bahwa semakin tinggi tingkat inflasi maka Retrun On Asset (ROA) semakin menurun, namun tidak signifikan baik pada PT. Bank Rakyat Indonesia Syariah.(Persero).Tbk maupun pada PT. Bank Rakyat Indonesia (Persero).Tbk. 
Adapun Pengaruh tingkat inflasi pada PT. Bank Rakyat Indonesia Syariah (Persero).Tbk lebih kecil dibandingkan dengan PT. Bank Rakyat Indonesia(Persero).Tbk. Hal ini ditunjukan dengan nilai coefficients pada PT. Bank Rakyat Indonesia Syariah (Persero).Tbk sebesar $(-0,0225)$ yang artinya apabila tingkat inflasi naik sebesar $1 \%$ maka Retrun On Asset (ROA) akan menurun sebasar 0,0225\% sedangkan pada PT. Bank Rakyat Indonesia(Persero).Tbk. memiliki nilai coefficients sebesar $(-0,1781)$ yang artinya apabila tingkat inflasi naik sebesar 1\% maka Retrun On Asset (ROA) akan menurun sebasar 0,1781\%.

Alasan yang melatarbelakangi hasil dari pada penelitian ini adalah kenaikan tingkat inflasi pada dasarnya menggambarkan kenaikan harga barang - barang secara umum yang akan menyebabkan turunnya nilai uang yang beredar dimasyarakat, hal ini juga disebabkan karena masyarakat akan cenderung mempergunakan hartanya untuk mencukupi biaya pengeluaran akibat naiknya harga-harga barang secara umun hal ini akan berdampak pada mengurangnya nilai riil tabungan dan selanjutnya berdampak negatif pada bank konvensional Dewi, 2018, hlm. 125).

Sedangkan pada bank syariah inflasi memiliki dampak yang lebih kecil, hal ini disebabkan bank syariah tidak menggunakan sistem bunga melainkan menggunakan sistem bagi hasil sehingga uang yang dikelola bank syariah tidak terlalu berpengaruh apabila terjadi peningkatan inflasi seperti halnya pada bank konvensional (Kusuma, 2018, hlm. 45).

Namun dampak inflasi pada kedua bank tersebut, tidak memiliki dampak yang signifikan pada proftabilitas, baik bank syariah maupun bank konvensional ini disebabkan karena tingkat inflasi pada periode tersebut masih cenderung dibawah $10 \%$ dan selanjutnya profitabilitas dalam hal ini Retrun On Asset(ROA) selain inflasi masih dipengaruhi oleh faktor faktor lainnya diantaranya BI Rate, nilai tukar dan Good Corporate Governance (GCG).

Penelitian ini sejalan dengan penelitian yang dilakukan oleh Edhi Satriyo Wibowo dan Muhammad Syaichu, yang menunjukan hasil bahwa inflasi memiliki arah negatif namun tidak memiliki pengaruh yang signifikan terhadap ROA bank syariah (Wibowo dan Syaichu, 2013, hlm. 8).

Penelitian ini juga mendukung penelitian yang dilakukan oleh Puguh Roni Prastowo, Rony Malavia, dan Budi Wahono yang menunjukkan hasil bahwa inflasi berpengaruh negatif tidak signifikan terhadap profitabilitas bank konvensional (Prastowo, Malavia, dan Wahono, t.t, 37). 


\section{KESIMPULAN DAN SARAN}

\section{Kesimpulan}

a. Inflasi memiliki pengaruh negatif dan tidak signifikan terhadap variabel terikat Retrun On Asset (ROA) bank syariah. Dengan tingkat signifikansi 0,1805 lebih besar dari 0,05 dan nilai coefficients tingkat inflasi sebesar $(-0,0225)$. Hal ini berarti bahwa setiap kenaikan $1 \%$ variabel Inflasi maka akan menurunkan nilai ROA sebesar 0,0225\%.

b. Inflasi memiliki pengaruh negatif dan tidak signifikan terhadap variabel terikat Retrun On Asset (ROA) bank konvensional. Dengan tingkat signifikansi 0,1199 lebih besar dari 0,05 dan nilai coefficients tingkat inflasi sebesar $(-0,1781)$. Hal ini berarti bahwa setiap kenaikan $1 \%$ variabel Inflasi maka akan menurunkan nilai ROA sebesar $0,1781 \%$.

\section{Saran}

Hasil dari penelitian ini diharapakan dapat menjadi masukan bagi pihak yang berkepentingan khususnya bank syariah untuk mengambil keputusan dalam menentukan kebijakan perusahaan.

Adapun saran yang penulis berikan untuk penelitian selanjutnya yaitu :

a. Penelitian yang akan datang diharapkan agar menambah variabel selain inflasi yang dapat berpengaruh pada profitabilitas.

b. Peneliti selanjutnya diharapkan dapat memperluas objek penelitian tidak hanya pada satu bank agar hasil nya dapat digeneralisasi untuk lembaga perbankan lainnya.

c. Peneliti selanjutnya disarankan untuk menggunakan data dengan rentan waktu yang lebih lama agar dapat menggambarkan kondisi yang sebenarnya.

\section{DAFTAR REFERENSI}

Adiwarman Karim. Ekonomi Makro Islami. Jakarta: Raja Grafindo Persada, 2017.

Afifah Dian Kusuma. "Pengaruh Inflasi, BI Rate, Nilai Tukar Mata Uang, CAR, NPF Dan FDR Terhadap Profitabilitas Bank Umum Syariah Di Indonesia.” Universitas Islam Indonesia, 2018.

Darsono, Siti Astiyah, Harisman, Ali Sakti, Ascarya, Androecia Darwis, Enny Tin Suryanti, dan Siti Rahmawati. Perbankan Di Indonesia Kelembagaan Serta Tantangan Ke Depan. Jakarta: PT. Raja Grafindo Persada, 2017.

Edhi Satriyo Wibowo, dan Muhammad Syaichu. "Analisis Pengaruh Suku Bunga, Inflasi, CAR, BOPO, NPF Terhadap Profitabilitas Bank Syariah.” Diponegoro Journal Of Management 2 (2013).

Edi Riadi. Statistika Penelitian (Analisis Manual dan IBM SPSS). Yogyakarta: CV. Andi Offset, 2016.

Eva Sri Wahyuni. "Pengaruh Inflasi Dan Suku Bunga Bi Terhadap Profitabilitas Bank Periode 2006-2010 : Perbandingan Antara Bank Syariah Dan Bank Konvensional.” Universitas Negeri Jakarta, 2016. 
Ghozali I. Aplikasi Analisis Multivariate dengan Program IBM SPSS 23.Edisi Ke8. Semarang: Universitas Diponogoro, 2016.

Heri Sudarsono. bank Dan Lembaga Keuangan Syariah Deskripsi dan Ilustrasi. Yogyakarta: Ekonisia, 2008.

Kasmir. Analisis Laporan Keuangan. Jakarta: PT Raja Grafindo Persada, 2014.

—. Analisis Laporan Keuangan Edisi Ke-3. Jakarta: Rajawali Pers, 2010.

—. Bank Dan Lembaga Keuangan Lainnya. PT Raja Grafindo Persada, 2008.

—. Manajemen Perbankan Edisi Revisi. Jakarta: Rajawali Pers, 2017.

Malayu S.P. Hasibuan. Dasar - Dasar Perbankan Ceteakan Kesebelas. Jakarta: PT. Bumi Aksara, 2017.

Muhammad. Manajemen Bank Syariah. Yogyakarta: (UPP) AMPY YKPN, 2005.

Muhardi, dan Wenner R. Analisis Laporan Keuangan, Proyeksidan Valuasi Saham. Jakarta: Salemba Empat, 2013.

Oktavia Rosana Dewi. "Pengaruh Dana Pihak Ketiga, Inflasi, BI Rate, dan Kurs terhadap Profitabilitas Perbankan Syariah Di Indonesia Periode 2013 2017." Universitas Islam Negeri Raden Intan Lampung, 2018.

PSAK No. 31 Tentang Akuntansi Perbankan

Puguh Roni Prastowo, Rony Malavia, dan Budi Wahono. "Analisis Pengaruh Inflasi, Suku Bunga Dan Nilai Tukar Terhadap Profitabilitas Perbankan." E - Jurnal Riset Manajemen PRODI MANAJEMEN Fakultas Ekonomi Dan Bisnis Unisma, t.t.

Sugiyono. Metode Penelitian Bisnis. Edisi 1. Bandung: Alfabeta, 2003.

Trusadini P. Usanti, dan Abd. Shomad. Hukum Perbankan. Jakarta: Kencana, 2016.

U Husein. Metode Penelitian untuk Skripsi dan Tesis. Rajawali: Jakarta, 2013.

Undang - Undang No. 10 Tahun 1998 Tentang Perbankan

Undang - Undang No. 21 Tahun 2008 Tentang Bank Syariah

V Wiratna Sujarweni. Analisis Laporan Keuangan Teori, Aplikasi dan Hasil Penelitian. Yogyakarta: Pustaka Baru Press, 2017.

Zainuddin Ali. Hukum Perbankan Syariah. Jakarta: Sinar Grafika, 2008.

www.bi.go.id

www.kbbi.com

www.ojk.go.id 